Cereal Research Communications 43(2), pp. 336-343 (2015)

DOI: $10.1556 /$ CRC.2014.0046

First published online 4 February, 2015

\title{
Genetics of Starch Content and its Correlations with Agro-morphological Traits in Sorghum
}

\author{
M. SWARnalatha, S. Audilakshmi*, C.V. Ratnavathi, B. DAYAKar RaO and J.V. PATIL \\ Directorate of Sorghum Research (previously, National Research Centre for Sorghum), \\ Hyderabad, India - 500030 \\ (Received 19 January 2014; Accepted 18 August 2014; \\ Communicated by R.N. Chibbar)
}

\begin{abstract}
Sorghum can be an alternative to corn for industrial uses, especially in drought prone areas of the world. Sorghum cultivars with high potential of grain and starch yields are needed to continuously meet the industrial demands. We have studied the genetics of grain yield and starch content of sorghum to decide the breeding procedure to develop suitable cultivars for starch industry. The genetic material from $8 \times 8$ diallel ( $28 \mathrm{~F}_{1}$ and 8 parents) was grown in a randomized complete block design, with three replications at Directorate of Sorghum Research, Hyderabad, India. Observations were recorded on seven agro-morphological and two grain quality traits including grain yield and starch content. Correlation studies revealed that the grain hardness was negatively correlated to starch and positively correlated to grain yield, panicle weight and days to flowering. Variance due to specific combining ability effects was greater in magnitude for both starch content and grain yield. Bi-parental crossing in $\mathrm{F}_{2}$ will help in getting pure lines with high starch content and high grain yield. The parents chosen for breeding program need to be good combiners for starch and grain yields to obtain superior hybrid. One MS line, 422B was a good combiner for grain yield, high starch content and 100 grain weight, and had good per se performance.
\end{abstract}

Keywords: correlations, general combining ability effects, specific combining ability effects, Sorghum bicolor

\section{Introduction}

Sorghum is one of the world's most important nutritious coarse cereal crops and now gaining importance as an industrial crop. World over sorghum is used for human consumption, animal feed, starch, and in alcohol industry. Starch is the main source of energy in all the staple foods and feeds in the world. It is also becoming an important industrial raw material. Approximately, 60 million tonnes of starch are extracted annually worldwide from various crops, of which approximately $60 \%$ is used in foods and $40 \%$ in pharmaceuticals and non-food applications (Burrell 2003). Maize starch is the most popular starch with industries as there is an assured supply from the USA.

* Corresponding author; E-mails: audilakshmi@sorghum.res.in; audilakshmi@rediffmail.com; Phone: +91 40 24015349; Fax: +91 4024016378. 
Maize and sorghum fall under broad category of coarse cereals grown in similar agroclimate regions of production competing with each other in production areas in India and South East Asia. The trend of genetic gain (high productivity and production) seems unable to meet the fast growing demand of maize in India (Singh et al. 2012). Comparative price trends of rainy season sorghum and maize over years indicate that sorghum has a price advantage over maize from 7-37\%, therefore it could partly replace/complement maize in its industrial uses as an economically cheaper alternative (Dayakar et al. 2003). While the growth in maize production is $10-12 \%$ (according to USDA), the growth in starch industry is $15 \%$ (put together with beverages), indicating anticipated shortages in the domestic maize supply, which may be replaced by sorghum which is a close alternative raw material with price and other advantages such as assured supply. Though currently 2.50 million tonnes of sorghum is estimated to be the demand for sorghum grain to be used in starch industry (starch/ potable alcohol); it is estimated that it will be quadrupled by $2050 \mathrm{AD}$ (Tonapi et al. 2011). These days in general, the availability of corn to the starch industry is decreasing gradually because of its increased demand in industries involved in the production of breakfast cereals, snacks, etc.

Sorghum with its rich starch content (approximately 70\%) and potential for industrial applications (Zhan et al. 2003a) can be exploited for starch production. Maize starch is extensively studied (Li et al. 2013); however there are very few reports on sorghum starches. Sorghum starch is technically equivalent to corn starch in its functionality (Freeman and Watson 1971). Sorghum starch plays important role in food products and ethanol fermentation (Park et al. 2006). Starch content has been positively correlated to ethanol yields in sorghum (Zhan et al. 2003b). Sorghum has polyphenols which influence starch colour and properties (Beta and Corke 2001). Pedersen et al. (2007) found that the mean gelatinization onset, peak and end temperatures were significantly lower for wild types than those of the waxy sorghum genotypes. Significant genetic variation was observed within genotypic classes, suggesting influence of additional modifying genes in affecting sorghum starch structure.

Industries prefer low cost raw material. For sorghum to be competitive with other crops, productivity and starch content need to be increased in the cultivars to reduce the cost of production of the industrial products. Globally, there is a requirement of sorghum hybrids with high potential for both grain and starch yields. Farmers will benefit with premium price for such end-product specific hybrids, and industry by providing superior quality low cost raw material. Hence there is a need to develop high starch content and high grain yield cultivars to make them useful in starch and ethanol industries. Knowledge of the nature of gene action allows breeders for optimizing their breeding program. Understanding of the relationship of starch with important agronomic genetic traits can facilitate development of genotypes with high starch content and grain yield. Hence our objective was to understand the genetics of high starch content and its relationship with other agro-morphological traits in sorghum. 


\section{Materials and Methods}

The experimental material comprised of eight non-restorer $\mathrm{B}$ lines (female parents of hybrids): 27B, 296B, 111B, 422B, 463B, 356B, 304B and 332B. 27B is a female parent of a commercial hybrid CSH $16 ; 296 \mathrm{~B}$ is a female parent for 5 commercial hybrids; $463 \mathrm{~B}$ is a female parent of a superior hybrid SPH 1148; and 111B, 422B, 356B, 304B, and 332B are female parents of newly developed hybrids.

The eight $\mathrm{B}$ lines were crossed among themselves in a half diallel fashion and $28 \mathrm{~F}_{1}$ seed were developed. The genetic material from $8 \times 8$ diallel $\left(28 F_{1}\right.$ and 8 parents $)$ was grown in a randomized complete block design, with three replications during rainy seasons of 2008 (precipitation during crop season: $887 \mathrm{~mm}), 2009(460 \mathrm{~mm})$, and 2010 (903 $\mathrm{mm})$ at Hyderabad $\left(17^{\circ} 27^{\prime} \mathrm{N}\right.$ latitude and $78^{\circ} 28^{\prime} \mathrm{E}$ longitude with an altitude of 524.6 metres above the sea level), India. Each entry was planted in a single row of $4 \mathrm{~m}$ length with $0.6 \mathrm{~m}$ spacing between the rows and $15 \mathrm{~cm}$ between plant to plant. Recommended agronomic practices were followed throughout the crop season. Atrazine $(1.0 \mathrm{~kg} / \mathrm{ha}$ of active ingredient) was applied immediately after sowing. A basal fertilizer dose of $42 \mathrm{~kg} / \mathrm{ha} \mathrm{N}$, $42 \mathrm{~kg} / \mathrm{ha} \mathrm{P}_{2} \mathrm{O}_{5}$ was applied just before sowing, in the second week of June 2008, 2009 and 2010 , and a top dressing of $46 \mathrm{~kg} / \mathrm{ha} \mathrm{N}$ was applied one month after germination (floral initiation stage) in the third week of July. Data was recorded on the seven agro-morphological and two grain quality traits. The details are given below.

\section{Agro-morphological traits}

Morphological characters such as days to 50 percent flowering, plant height, panicle length, panicle width, panicle weight, grain weight, 100-grain weight were recorded and starch content was analyzed. Observations were recorded on five randomly labeled competitive plants in each replication. Treatment means were calculated from the data collected on these plants.

\section{Grain quality traits}

Two grain quality traits, grain hardness and starch content were assessed in each entry.

Grain hardness (sec): The grain hardness was assessed according to the method followed by Pomeranz et al. (1985).

Starch content (\%): Starch content was estimated by Southgate (1976). Defatted grain meal (flour) $(75 \mathrm{mg}$ ) was taken for the estimation of starch and it was gelatinized for 90 minutes at $19 \mathrm{lb}$ pressure and hydrolyzed enzymatically with $25 \mathrm{mg}$ of amyloglucosidase enzyme (Sigma) comprising of 5.75 units and $2 \mathrm{M}$ sodium acetate buffer. The hydrolyzed sugars were estimated by phenol-sulphuric acid method after diluting the extract (Dubois et al. 1956) and the absorbance was read at $490 \mathrm{~nm}$ in a UV-Spectrophotometer (Schimadzu, Japan). Percent starch was calculated using 0.9 as conversion factor for sugars and the required dilution factors were used. 


\section{Statistical analysis}

Simple linear correlations were computed with Statistix version 8.1 (Analytical Software, Tallahassee, FL, USA). Combining ability analysis was carried out according to Method II, Model I (Griffing 1956). Pooled estimates of general combining ability (gca) and specific combining ability (sca) variances were made (Singh 1973) using Windostat version 7.5 (Indostat Services, Hyderabad, India).

\section{Results}

The starch content in B lines varied from 61 to $67 \%$ and B lines 27B, 422B and 356B recorded highest starch content (66 to 67\%) (Table 1). Grain yield ranged from 26 to 46 $\mathrm{g} / \mathrm{plant}$ and highest grain yields were recorded by B lines 332B and 422B. The flowering ranged from 69 to 76 days; plant height from 110 to $212 \mathrm{~cm}$, panicle length from 19 to $29 \mathrm{~cm}$; panicle width from 3.5 to $4.5 \mathrm{~cm}$; panicle weight from 41 to $61 \mathrm{~g} / \mathrm{plant} ; 100$ grain weight from 1.6 to $2.9 \mathrm{~g}$ and grain hardness varied from 17 to 42 seconds. The correlation studies showed strong significant negative correlation between starch content and grain hardness (Table 2). Also, significant negative correlations were found between starch and plant height, and days to flower. However starch was not correlated to grain yield and grain yielding attributes.

Table 1. Means for starch content and various agronomic traits in sorghum male sterile (B) lines

\begin{tabular}{lccccccccc}
\hline $\begin{array}{l}\text { Geno- } \\
\text { types }\end{array}$ & $\begin{array}{c}\text { Days to } \\
\text { flowering }\end{array}$ & $\begin{array}{c}\text { Plant } \\
\text { height, } \\
\mathrm{cm}\end{array}$ & $\begin{array}{c}\text { Panicle } \\
\text { length, } \\
\mathrm{cm}\end{array}$ & $\begin{array}{c}\text { Panicle } \\
\text { width, } \\
\mathrm{cm}\end{array}$ & $\begin{array}{c}\text { Panicle } \\
\text { weight, } \\
\mathrm{g}\end{array}$ & $\begin{array}{c}\text { Grain } \\
\text { yield, } \\
\text { g/plant }\end{array}$ & $\begin{array}{c}\text { 100-grain } \\
\text { weight, } \\
\mathrm{g}\end{array}$ & $\begin{array}{c}\text { Grain } \\
\text { hardness, } \\
\text { seconds }\end{array}$ & $\begin{array}{c}\text { Starch } \\
\text { content, } \\
\%\end{array}$ \\
\hline 27B & 71 & 154 & 29 & 4.1 & 43 & 26 & 2.3 & 22 & 67 \\
111B & 69 & 152 & 25 & 4.3 & 46 & 32 & 2.5 & 31 & 61 \\
422B & 70 & 146 & 25 & 3.9 & 55 & 38 & 2.5 & 22 & 66.1 \\
463B & 70 & 110 & 19 & 4 & 47 & 31 & 1.6 & 29 & 64.6 \\
356B & 76 & 212 & 24 & 3.6 & 41 & 30 & 2.9 & 21 & 66.7 \\
304B & 73 & 140 & 22 & 3.9 & 44 & 30 & 2.5 & 34 & 64 \\
332B & 76 & 155 & 22 & 4.5 & 61 & 46 & 2.1 & 42 & 63.1 \\
296B & 73 & 134 & 21 & 3.5 & 50 & 33 & 1.8 & 17 & 65.3 \\
\hline LSD & 2.76 & 27.81 & 4.11 & 0.55 & 20.31 & 16.26 & 0.35 & 9.51 & 2.38 \\
$(P=0.05)$ & & & & & & & & & \\
\hline
\end{tabular}

The mean squares due to genotypes ( $\mathrm{F}_{1}$ and parents) were significantly different for all the traits studied. Components of genetic variance for all parents were highly significant for all the traits except panicle weight (Table S1*). Highly significant differences for parents vs. crosses and among the crosses $\left(\mathrm{F}_{1}\right)$ were also observed for all the traits. Environment effects were highly significant for all the traits (Table S1). General combining ability effects (gca) and specific combining ability effects (sca) for all the traits were highly sig-

* Further details about the Electronic Supplementary Material (ESM) can be found at the end of the article. 
Table 2. Simple correlations between starch and other agronomic traits

\begin{tabular}{lcccccccc}
\hline & $\begin{array}{c}\text { Days to } \\
\text { flowering }\end{array}$ & $\begin{array}{c}\text { Plant } \\
\text { height }\end{array}$ & $\begin{array}{c}\text { Panicle } \\
\text { length }\end{array}$ & $\begin{array}{c}\text { Panicle } \\
\text { width }\end{array}$ & $\begin{array}{c}\text { Panicle } \\
\text { weight }\end{array}$ & $\begin{array}{c}\text { Grain } \\
\text { yield }\end{array}$ & $\begin{array}{c}\text { 100-grain } \\
\text { weight }\end{array}$ & $\begin{array}{c}\text { Grain } \\
\text { hardness }\end{array}$ \\
\hline Plant height & $0.19^{* * *}$ & & & & & & & \\
Panicle length & -0.21 & 0.0037 & & & & & & \\
Panicle width & -0.04 & $0.19^{* * *}$ & $0.26^{* * *}$ & & & & & \\
Panicle weight & $0.1117^{*}$ & $0.18^{* * *}$ & $0.38^{* * *}$ & $0.54^{* * *}$ & & & & \\
Grain weight & $0.122^{*}$ & 0.12 & $0.35^{* * *}$ & $0.45^{* * *}$ & $0.93^{* * *}$ & & & \\
100-grain weight & 0.09 & $0.41^{* * *}$ & $0.26^{* * *}$ & $0.23^{* * *}$ & $0.46^{* * *}$ & $0.45^{* * *}$ & & \\
Grain hardness & $0.36^{* * *}$ & 0.05 & -0.11 & 0.09 & $0.34^{* * *}$ & $0.38^{* * *}$ & 0.06 & \\
Starch & $-0.13^{*}$ & $-0.13^{*}$ & 0.04 & -0.0476 & -0.1004 & -0.0964 & -0.0305 & $-0.15^{* * *}$ \\
\hline
\end{tabular}

*** Significant at $P=0.001$; * Significant at $P=0.05$

nificant including starch content and grain yield. The mean sum of squares due to genotype $\times$ environment and hybrids $\times$ environment were highly significant for the traits grain yield, 100-grain weight, grain hardness and starch content. So we partitioned the mean sums of squares into gca $\times$ Environment $(E)$ interaction and sca $\times$ Environment $(E)$ interaction (Table S1). In this study, gca $\times \mathrm{E}$ and sca $\times \mathrm{E}$ were highly significant for grain weight, 100-grain weight, grain hardness and starch content. MS lines 27B, 422B, and 356B showed significant gca effects for starch content (Fig. S1). Similarly, significant positive gca effects were obtained for 422B, and 332B for grain yield; and 463B, 304B, and $332 \mathrm{~B}$ for grain hardness. Though $422 \mathrm{~B}, 27 \mathrm{~B}$, and 356 $\mathrm{B}$ had significant positive gca effects for starch content, 422B had positive gca effects for grain yield; 27B and 356B had negative gca effects for grain yield and were not desirable lines. However, in comparison to the other two lines, 422B had high starch and grain yields.

\section{Discussion}

B lines showed large variability for all the traits studied. The analysis of variance also showed that the treatments are significantly different for the traits. Though Buffo et al. (1998) reported that starch was not correlated to grain hardness in sorghum; similar to our results, Pedersen and Kofoid (2004) found that starch was negatively correlated to kernel hardness in sorghum. Similarly, the grain hardness was negatively correlated with the starch in barley (Henry and Cowe 1990), and in wheat (Salmanowicz et al. 2012). Buffo et al. (1998) further reported that they obtained contradictory results as against those of Subramanian and Jambunathan (1981) and most likely, this was due to genetic differences in tested sorghum samples. It is usual expectation that the hardest endosperm contains highest protein (and hence the lowest starch) content; since grain hardness in cereals is positively correlated to protein content (Groos et al. 2004).

The parents, hybrids and parent vs. hybrids contribute differently for combining ability. There were differences in performance of genotypes as parents in hybrid combinations as the gca effects were significant for all the traits. The genetic analysis for a partial diallel revealed the presence of additive and non-additive effects of the genes in the inheritance 
of starch and all the traits studied. The starch content in 'maize' is governed by both additive and non-additive gene actions (Joshi et al. 1998; Dadheech and Joshi 2007a). The ratio of gca variance to sca variance varied from 0.72 to 1.02 for traits days to flower, plant height, panicle length, 100-grain weight and grain hardness and the comparison of additive variance and dominance variance (Table 3 ) indicated that these traits are predominantly governed by additive gene action as reported for grain hardness (Ibrahim et al. 1985; Aruna and Audilakshmi 2004). Therefore, breeding procedure such as simple recurrent selection or back crossing can increase frequency of desirable genes. However, for the traits panicle width, panicle weight, grain yield, and starch content, dominance variance was higher than additive variance, indicating that the non-additive (dominance and epistatis) gene effects were more important for the traits. Zdunic et al. (2008) reported dominance and epistatis interaction to be important for starch and grain yields in maize. Hybrid breeding will be useful, as in hybrids, heterozygous condition is fixed. Bi-parental crossing in $\mathrm{F}_{2}$ and further advancing of lines will help in developing pure lines with high starch content and high grain yield.

Table 3. Estimates of genetic components of variation for various traits in sorghum

\begin{tabular}{lccccccccc}
\hline & $\begin{array}{c}\text { Days to } \\
\text { flowering }\end{array}$ & $\begin{array}{c}\text { Plant } \\
\text { height }\end{array}$ & $\begin{array}{c}\text { Panicle } \\
\text { length }\end{array}$ & $\begin{array}{c}\text { Panicle } \\
\text { width }\end{array}$ & $\begin{array}{c}\text { Panicle } \\
\text { weight }\end{array}$ & $\begin{array}{c}\text { Grain } \\
\text { yield }\end{array}$ & $\begin{array}{c}\text { 100-grain } \\
\text { weight }\end{array}$ & $\begin{array}{c}\text { Grain } \\
\text { hardness }\end{array}$ & $\begin{array}{c}\text { Starch } \\
\text { content }\end{array}$ \\
\hline $\begin{array}{l}\text { Additive } \\
\text { variance }\end{array}$ & 3.36 & 503.9 & 7.74 & 5.58 & 29 & 29 & 8 & 42 & 0.4 \\
$\begin{array}{l}\text { Dominance } \\
\text { variance }\end{array}$ & 2.25 & 246.9 & 5.20 & 24.99 & 329 & 162 & 6 & 19 & 2 \\
$\begin{array}{l}\mathrm{h}^{2} \mathrm{Ns} \\
\text { gca/sca }\end{array}$ & 0.4 & 0.6 & 0.4 & 0.1 & 0.1 & 0.1 & 0.4 & 0.3 & 0.0 \\
ratio & 0.75 & 1.02 & 0.74 & 0.11 & 0.04 & 0.09 & 0.72 & 1.09 & 0.09 \\
\hline
\end{tabular}

$\mathrm{h}^{2} \mathrm{Ns}=$ narrow sense heritability

Physicochemical and functional properties of sorghum cultivar starches were influenced by the genotype and the environment (Boudries et al. 2009); and starch content in maize was influenced by genotype $\times$ environment interaction (Dadheech and Joshi 2007b). Similar results were obtained for grain weight, 100-grain weight, grain hardness and starch content indicating that the choice of parents for breeding should be based on combiners and $\mathrm{F}_{1}$ combinations which show least interaction with environments. MS lines 27B, 422B and 356B were good general combiners for starch content (Fig. S1). Similarly, $422 \mathrm{~B}$ and 332B for grain yield; and 463B, 304B, 332B for grain hardness were good general combiners.

In conclusion, same breeding procedures are to be followed to incorporate both high starch content and high grain yield genes, as the genetics for grain yield and starch content is predominantly governed by non-additive gene action. The lines which were good combiners for starch content and grain yield, also showed good per se performance for the traits, especially B line, 422B. To obtain superior hybrids for high starch and grain yield traits, choosing the parents should be such that, either one parent should be good combiner 
for both the traits, or one parent to is be a good combiner for starch and the second a good combiner for grain yield.

\section{References}

Aruna, C., Audilakshmi S. 2004. Genetic architecture of grain hardness - a durable resistance mechanism for grain moulds in sorghum [Sorghum bicolor (L.) Moench]. Indian J. Genetics and Plant Breeding 64:35-38.

Beta, T., Corke, H. 2001. Genetic and environmental variation in sorghum starch properties. Journal of Cereal Science 34:261-268.

Boudries, N., Belhaneche, N., Nadjemi, B., Deroanne, C., Mathiouthi, M., Roger, B., Sindic, M. 2009. Physicochemical and functional properties of starches from sorghum cultivated in the Sahara of Algeria. Carbohydrate Polymers 78:475-480

Buffo, R.A., Weller, C.L., Parkhurst, A.M. 1998. Relationships among grain sorghum quality factors. Cereal Chem. 75:100-104.

Burrell, M.M. 2003. Starch: The need for improved quality or quantity - an overview. J. Exp. Bot. 54:451-456.

Dadheech, A., Joshi, V.N., 2007a. Heterosis and combining ability for quality and yield in early maturing single cross hybrids of maize (Zea mays L.). The Indian J. of Agricultural Sciences 41:210-214.

Dadheech, A., Joshi, V.N. 2007b. Stability analysis for quality traits in maize (Zea mays L.). Agricultural Science Digest 27:26-29.

Dayakar, R.B., Binu, M., Bharath Kumar, K.A., Karthikeyan, K., Hyma Jyothi, S., Parwaz Shahid, Ratnavathi, C.V., Seetharama, N. 2003. Industrial utilization of sorghum in India - Status and prospects. NATP (NRCS) Series No. 2. Rajendranagar 500030, Andhra Pradesh, India: National Research Centre for Sorghum. 20 pp.

Dubois, M., Gilles, K.A., Hamilton, J.K., Rebers, P.A., Smith, F. 1956. Colorimetric method for determination of sugars and related substances. Analytical Chem. 28:350-356.

Freeman, J.E., Watson, S.A. 1971. Influence of sorghum endosperm pigments on starch quality. Cereal Science Today 16:378-381.

Griffing, B. 1956. Concept of general and specific combining ability in relation to diallel crossing systems. Austr. J. Biological Sciences 9:463-493.

Groos, C., Bervas, E., Charmet, G. 2004. Genetic analysis of grain protein content, grain hardness and dough rheology in a hard bread wheat progeny. J. Cereal Sci. 40:93-100.

Henry, R.J., Cowe, I. A. 1990. Factors influencing the hardness (milling energy) and malting quality of barley. J. of Institute of Brewing 96:135-136.

Ibrahim, O.E., Nyquist, W.E., Axtell, J.D. 1985. Quantitative inheritance and correlations of agronomic and grain quality traits of sorghum. Crop Sci. 25:649-654.

Joshi, V.N., Pandiya, N.K., Dubey, R.B. 1998. Heterosis and combining ability for quality and yield in early maturing single cross hybrids of maize. Indian J. of Genetics and Plant Breeding 58:519-524.

Li, J., Baroja-Fernández, E., Bahaji, A., Muñoz, F.J., Ovecka, M., Montero, M., Sesma, M.T., Alonso-Casajús, N., Almagro, G., Sánchez-López, A.M., Hidalgo, M., Zamarbide, M., Pozueta-Romero, J. 2013. Enhancing sucrose synthase activity results in increased levels of starch and ADP-glucose in maize (Zea mays L.) seed endosperms. Plant and Cell Physiol. 54:282-294.

Park, S.H., Bean, S.R., Wilson, J.D., Schober, T.J. 2006. Rapid isolation of sorghum and other cereal starches using sonication. Cereal Chem. 83:611-616.

Pedersen, J.F., Graybosch, R.A., Funnell, D.L. 2007. Occurrence of the waxy alleles wxa and wxb in waxy sorghum plant introductions and their effect on starch thermal properties. Crop Sci. 47:1927-1933.

Pedersen, J.F., Kofoid, K.D. 2004. Variability and relationships among 12-hour IVDMD, starch, oil, protein, and physical characteristics of 16 sorghum conversion lines. Euphytica 130:261-266.

Pomeranz, Y., Czuchajowska, Z., Martin, C.R., Lai, F.S. 1985. Determination of corn hardness tester. Cereal Chem. 62:108-112.

Salmanowicz, B.P., Adamsk, T., Surma, M., Kaczmarek, Z., Karolina, K., Kuczyńska, A., Banaszak, Z., Ługowska, B., Majcher, M., Obuchowski, W. 2012. The relationship between grain hardness, dough mixing parameters and bread-making quality in winter wheat. Int. J. Mol. Sciences 13:4186-4201.

Singh, D. 1973. Diallel analysis over different environments - I. Indian J. Genetics and Plant Breeding 33:127-136.

Cereal Research Communications 43, 2015 
Singh, N., Rajendran, R.A., Shekhar, M., Jat, S.L., Sai Kumar, R. 2012. Rabi maize opportunities challenges. Directorate of Maize Research, Pusa Campus, New Delhi - 110 012, India. Technical Bullet, in No. 9. 32 pp.

Southgate, D.A.T. 1976. On Determination of Food and Carbohydrates. Applied Science Publishers Ltd., London, UK, pp. 52-55.

Subramanian, V., Jambunathan, R. 1981. Properties of sorghum grain and their relationship to roti quality. In: Rooney, L.W., Murphy, D.S. (eds), Proc. Int. Symp. on Sorghum Grain QUALITY. Int. Crops Res. Inst. Semi-Arid Tropics (ICRISAT). Patancheru, India. pp. 280-288.

Tonapi, A.V., Patil, J.V., Dayakar Rao, B., Elangovan, M., Venkatesh Bhat, B., Raghavendra Rao, K.V. 2011. Sorghum: Vision 2030. Rajendranagar, Hyderabad 500030 (AP), India: Directorate of Sorghum Research. $38 \mathrm{pp}$.

Zdunic, Z., Mijic, A., Dugalic, K., Simic, D., Brkic, J., Jeromela, A.M. 2008. Genetic analysis of grain yield and starch content in maize populations. Turkish J. of Agriculture and Forestry 32:495-500.

Zhan, X., Wang, D., Tuinstra, M.R., Bean, S., Seib, P.A., Sun, X.S. 2003a. Ethanol and lactic acid production as affected by sorghum genotype and location. Industrial Crops and Products 18:245-255.

Zhan, X., Wang, D., Sun, X.S., Kim, S., Fung, D.Y.C. 2003b. Lactic acid production using extrusion-cooked grain sorghum. Am. Soc. Agric. Engineers 46:589-593.

\section{Electronic Supplementary Material (ESM)}

Electronic Supplementary Material (ESM) associated with this article can be found at the website of CRC at http://www.akademiai.com/content/120427/

Electronic Supplementary Table S1. Pooled analysis of variance for different traits in sorghum

Electronic Supplementary Figure S1. General combining ability (gca) effects of sorghum B lines 